\title{
Linking Transformational Leadership Theory to the Practice of Academic Advising - A Conceptual Paper
}

\author{
Margaret Mbindyo \\ Millersville University \\ Rubab Jafry O'Connor \\ Carnegie Mellon University \\ Ankur Nandedkar \\ Millersville University
}

\begin{abstract}
The purpose of this article is to link Transformational Leadership Theory to the practice of academic advising. More specifically, we take a deep dive into the four I's of Transformational Leadership (Idealized Influence, Inspirational Motivation, Intellectual Stimulation \& Individualized Consideration) and connect them with the traits of academic advising. We emphasize the need to understand students and encourage them through the four I's as it is shown to positively predict academic success. In doing so, we highlight the similarities between TL theory and the practice of academic advising and argue that academic advisors can develop as transformational leaders and boost students' collegiate, career, and life goals. We argue that by training advisors to model the behaviors of transformational leaders, the process of advising can be improved tremendously. Our work extends the understanding of the role of TL on academic advising and student success. We provide a rationale for the positive relationship between TL theory and academic advising practices and how by integrating TL Theory into advising, advisors can become Transformational Leaders.
\end{abstract}

Keywords: transformational leadership, academic advising, student success

\section{INTRODUCTION}

College students come to campus with high expectations and rely on the people they find there to help them successfully transition to collegiate life. Each student faces unique challenges in this transition and academic advisors holds unique positions where they can play a key leadership role as an academic resource, a model of character, and a source of inspiration. Several studies have shown that strong leadership skills are needed to maximize advising or mentoring relationships with students (Sprately, 2020;

Green, 2016; Davis Jones, 2015; Koen \& Bitzer, 2010). Indeed, such leadership is needed at all levels of an institution to model character and to encourage, motivate and inspire students (Van Ameijde, Nelson, Billsberry \& Meurs, 2009). Therefore, it seems appropriate that advisors develop themselves as strong 
leaders to enhance student outcomes. This paper argues that a Transformational Leadership (TL) approach would provide a significant and congruous enhancement to current advising practice.

Traditional advising methods and TL techniques share complementary overlaps that warrant exploration. TL as applied in advising allows the advisor to incorporate behaviors that are likely to increase student motivation and success (Nandedkar, Mbindyo \& O'Connor, 2020). These behaviors include setting high expectations, creating measurable goals, encouraging self-management, openly sharing information and knowledge and intrinsic motivation. In addition, these behaviors allow advisors to serve as inspiration to their students through effective communication and by commitment to student's academic success. Emphasizing transformational attributes and leadership skills in advisors promotes highly skilled, positive and impactful agents of change (Kelly, 2003).

An advisor who embraces the tenets of TL is likely to,

- influence students through motivation while respecting their individuality.

- encourage students to seek help when they need it.

- help identify areas in need of improvement and help students to realign their goals for academic success.

- improve the mindset of students through proactive communication.

- show professionalism in all areas of their work.

- help with individual goal setting and goal commitment for students by holding them responsible for accomplishing those goals.

- empower students to develop leadership characteristics through mutual responsibility and trust.

Although several studies have noted that TL theory is applicable to advising (Kelly, 2003; Kincanon, 2009; Green 2016; Nandedkar, Mbindyo \& O'Connor, 2020; Pine, 2020), these studies have not examined the 4Is of TL in the context of the advising profession. In this respect, investigating the interplay of these factors may reveal critical leadership or professional development opportunities for advisors. Therefore, in this conceptual paper we aim to link TL theory to the practice of academic advising. We believe the TL theory can be applied to the practice of academic advising in a way that is particularly empowering to students given the role advisors play in the lives of the students.

The article begins with a definition of academic advising and a review of the characteristics of academic advisors. We then look at the TL framework, including the 4Is. In addition, we discuss the degree to which NACADA's core values may foster the development of transformational advisors by integrating TL theory and academic advising literature to provide a more detailed understanding of how advisors can develop to become transformational leaders or apply TL approaches in their practice. In addition, we will develop logical ties between advising and the "4I's" (individualized consideration, idealized influence, inspirational motivation, intellectual stimulation) which are at the core of TL. Finally, we will address the implication of TL to the advising profession by comparing the NACADA advising core values with the 4I's.

\section{DEFINING ACADEMIC ADVISING}

While there is no formal definition of academic advising due to the varied roles it plays across departments and institutions, researchers and academicians have made many attempts to capture its essence. At its most basic, an advisor's responsibility includes leading students in the appropriate direction through their college career (McClellan, 2007). The definition of academic advising can be further refined to include applying the knowledge of a particular field to empower students, the campus, and community members to successfully navigate academic interactions related to higher education (Larson, Johnson, AikenWisniewski, \& Barkemeyer, 2018). Young-Jones etal (2013) emphasize academic advising as an activity that enhances student experiences by helping them set professional and personal goals, by encouraging them to participate in co- curricular activities, and by making them aware of student development opportunities. Advisors establish a meaningful connection between the student and the institution (Morris \& Miller, 2007), coaching, teaching, college policy interpretation, advocacy etc. (McClellan \& Moser, 2011). Moreover, advisors play a key role in helping students through many transitions throughout their 
college journeys and in preparing them for the real-world through sound academic, career and social advice while modeling professional ethics.

"Academic advisors work with students to enable them to be confident and assertive in their own abilities to learn, generate, and apply new knowledge and to empower them to embrace their own knowing, learning, thinking, and decision making" (White, 2015, p. 272).

Gillispie (2003) notes the increasing level of involvement and presence of academic advisors in the development of college students and the educational paths they choose. Chickering, (1994) previously noted the important role of advisors in helping students become effective tool for their own lifelong learning and personal development. Gordon, Habley, and Grites (2008) emphasize that academic advising is an educational activity that depends on valid explanations of complex student behaviors and institutional conditions to assist college students in making and executing their educational and life plans. Finally, McMahan (2008) reminds us that the job of an academic advisor is a rewarding vocation that allows advisors who recognize important opportunities to make real differences in students' lives and in their academic aspirations.

\section{Academic Advisor Practices and Characteristics}

Academic advisors are uniquely positioned to assist students in reaching their goals due to their individualized interactions. For these interactions to be smooth and successful, academic advisors must possess certain key characteristics which include accurate knowledge of degree requirements, career paths, the logistics of course registration, and appropriate course load within academic disciplines. They must be able to monitor advisees' progress toward achieving declared educational goals by addressing both longterm needs and immediate challenges. They must also possess an array of soft skills (Crosbie, 2005) to engage advisees. Among the most useful of those characteristics is resourcefulness. An advisor cannot anticipate every need and cannot be an expert in every subject. Therefore, they must be able to use their developed networks when necessary.

In addition, it is helpful they possess a high level of resiliency and emotional intelligence (EI). In Caruso and Wolf's (2001) work on EI in the workplace, it was found that a manager's own emotional state can have an impact on the employees. Similarly, an academic advisors' emotional state can have a significant impact on their students. Marks and Wade (2015) argue that educators who complement their students positively can create positive expectations and can develop a more engaging relationship with advisees. This relationship is essential for advisors pursuing a holistic approach, which puts emphasis on the wellbeing of the students. For holistic advising to happen, academic advisors must be student-oriented, have an interest in and concern for students as individuals, be skilled in counseling and interpersonal relationships, be able to listen, and demonstrate patience, tolerance and trustworthiness (Schuh, Jones, Harper \& Associates, 2010).

\section{TRANSFORMATIONAL LEADERSHIP FRAMEWORK}

Originally introduced by Burns (1978), TL theory has been demonstrated to bring radical changes in the work environment by addressing follower needs for development and achievement (Conger, 1999). Transformational leaders have been depicted in the literature as visionary, empowering, social, passionate, and innovative (Hackman \& Johnson, 2004). Bass (1985) conceptualized TL behaviors into separate dimensions: idealized influence, inspirational motivation, individualized consideration, and intellectual stimulation (See Figure.1 below). 
FIGURE 1

\section{TRANSFORMATIONAL LEADERSHIP FRAMEWORK}

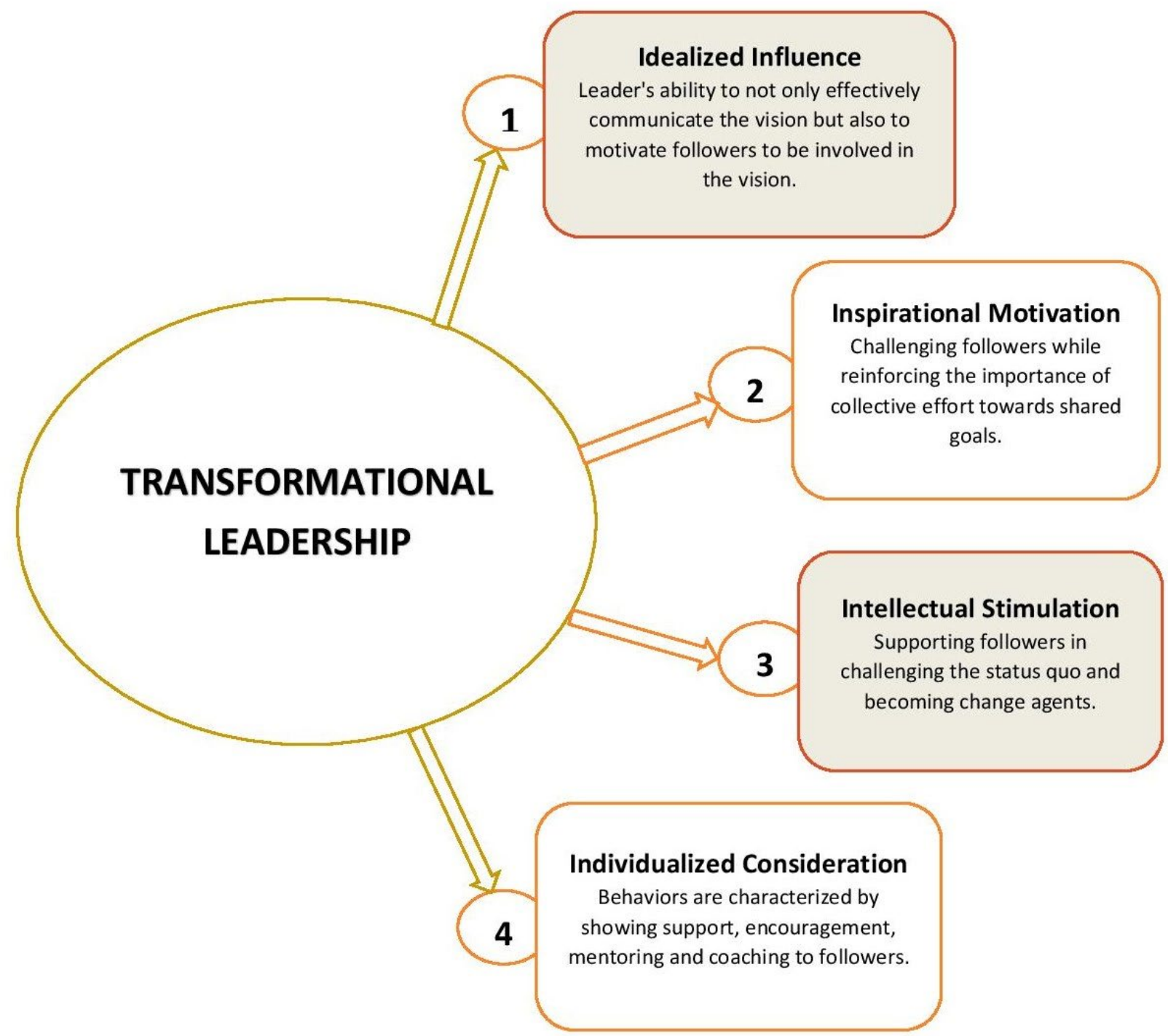

\section{HOW THE TRANSFORMATIONAL LEADERSHIP 4IS AFFECT ADVISING}

\section{Idealized Influence}

Idealized influence in TL plays a critical role in building trust, confidence, and respect (Bass, Avolio, Jung, \& Berson, 2003). People with idealized influence are focused, have a sense of purpose and take risks (Bass, 1998). Transformational leaders are regarded as role models because they can influence followers with their charisma or extraordinary personal characteristics. Bass (1999) emphasized idealized influence as a leader's ability to not only effectively communicate the vision but also to motivate followers to be involved in the vision. These behaviors are attributed with high levels of trust (Bass, 1985), strong emotions and identification with the leader (Yukl,2006). The behaviors are also associated with charisma, which in turn, is attributed with being enthusiastic about the work, being respected, and emphasizing the importance of mission to followers (Banerji \& Krishnan, 2000). Leaders demonstrate idealized influence when they contribute to organization's improvement by taking risks with their followers, celebrate follower's success, 
maintain consistency in their behavior and are dependable (Kirkbride, 2006; Kelloway, Barling, Kelley, Comtois, \& Gatien, 2003).

Idealized influence is very important from an advising standpoint because trust, mutual respect, and clear vision play a critical role in the advisee-advisor relationship. Advisors can help advisees develop a vision and provide a platform for success in college (Morris \& Miller, 2007), and their role is complex, and involves coaching, teaching, college policy interpretation, advocacy etc. (McClellan \& Moser, 2011). Advisors also mentor students in their academic career by assisting them to be more confident and assertive in their own abilities to learn, generate, and apply new knowledge; and empower students to embrace their own knowing, learning, thinking, and decision making" (White, 2015, p. 272). Thus, when advisors display charisma, establish a vision for students, celebrate their success, and maintain consistency in their behaviors, it helps them earn the trust and respect of students and enhances their advising efficacy (McClellan \& Moser, 2011; Johnson \& Grayson, 2005).

\section{Inspirational Motivation}

The second of the four I's, Inspirational Motivation, refers to the way leaders motivate and inspire their followers to commit to the vision and the mission of an institution, leading to better performance outcomes (Bass \& Riggio, 2006). In an organization, Inspirational Motivation is recognized as a key contributor to employee dedication and is applied by the leader to realize higher levels of employee engagement and effectiveness, which are connected to better work results (Gallup, 2017). Additionally, in his work, Bryman (2007) observed that leadership effectiveness in higher education is explored through the characteristics of leadership behavior that motivates others to do well. The focus of inspirational motivation is on influencing individual performance by enhancing motivation to achieve performance goals. In academic advising, it is associated with academic advisors helping students to create short term goals. In the same way academic advisors using Inspirational Motivation can help their students realize academic goals and success as well as creating a strong sense of academic success among students through inspirational sessions. Academic advisors can also use inspirational motivation to sustain student motivation towards better academic outcomes. Incorporating Inspirational motivation in their advising work by motivating students, academic advisors can yield intrinsic motivation, commitment, and effort, which culminate in improved academic performance in students (Zhang, Li, Ullrich, \& van Dick, 2015). Inspirational Motivation arises from the use of effective communication style of the leader. The academic advisor with inspirational motivation can motivate and inspire students towards academic success through encouragement and praise when students do well (McCleskey, 2014). In this regard, the academic advisor can promote academic interest, career enthusiasm, and optimism in their students by communicating high expectations.

\section{Intellectual Stimulation}

The Intellectual Stimulation dimension of TL encourages innovation and challenges the status-quo (Northhouse, 2010). Transformational leaders facilitate the development of new ideas by empowering followers to solve problems in unique ways using evidence-based practice (Barbuto 2005; Gheith 2010). The behaviors associated with Intellectual Stimulation include re-examining established assumptions, recognizing patterns that are difficult to conceptualize, encouraging followers to share their ideas without the apprehension of how the ideas may be perceived, and motivating the followers to challenge themselves (Kirkbride 2006). When used in the realm of student advising, Intellectual Stimulation can help students to become students independent thinkers and problem solvers. The advisor who intellectually stimulates advisees, creates an environment where they can question old assumptions and consider new ways of solving problems (Barbuto, etal, 2011). Thus, to create such an environment for advisees, advisors need to critically examine and embrace intellectual stimulation in their line of work.

The process of advising includes autonomy support (Surr, 2019). It describes how the actions of one person can enhance another individual's internal perceived locus of control, volition, and perceived choice during action (Reeve, Nix, \& Ham, 2003). Autonomy support strategies are shown to spur student's agency and ownership of their learning and play an instrumental role in developing student's capacity for goal setting, decision making and problem solving to ensure future success (Burt, Young-Jones, Yadon, \& Carr, 
2013). Advisors help students make choices about courses, degree planning, personal development, and career planning (Council for Advancement of Standards in Higher Education, 2014). All of these require careful analysis of a student's strengths and weaknesses in addition to critically thinking about the future. Intellectual stimulating behaviors within TL are shown to enhance internal motivation and promote critical thinking of followers (Bolkan, Goodboy, \& Griffin, 2011). In addition, Higgins (2017) argues that "through the education process of advising, an advisor can guide students through meaning making, skill identification and development, critical thinking, scaffolding of knowledge, and acquisition of transferable skills" (pg.7). Thus, advisors can enhance their advisees' critical thinking and promote deeper learning by intellectually stimulating them.

\section{Individualized Consideration}

Individualized Consideration refers to the extent to which a leader attends to each follower's needs and is a mentor, coach or guide to the follower (Bass, \& Riggio, 2006). Bass \& Riggio (2006) further stress that transformational leaders personalize their conversations with the followers and help them develop and grow into whole persons. The leader listens to the concerns and needs of each follower and provides support and is empathic of each person's situation and background (Towler, 2019). Transformational leaders' pay personal attention to their followers by showing genuine concern for the needs and feelings of followers and that helps in developing the follower's leadership potential (Bass \& Riggio, 2006). Hence, Individualized Consideration requires active listening, being empathic of others' situations, genuine concern for others' needs and feelings and keen interest in followers' development and growth.

Individualized Consideration holds a very important role from an advising standpoint. Keen interest in students' development and growth is one of the core values of developmental academic advising. According to (Grites, 2013), developmental academic advising is a holistic process that is based on student growth and takes students from their point of entry, along each dimension (personal, career, and educational), and facilitates growth. (McClellan \& Moser, 2011) stress that academic advisors are coaches of student success who help students with decision making and performance improvements by using coaching-related activities and procedures. Listening with empathy is also one of the core values of academic advising and according to (Smith III, 2020) it is identified to achieve various beneficial ends. Thus, academic advisors like transformational leaders can provide Individualized Consideration to their advisees by acting as coaches, mentors and guides.

\section{DISCUSSION}

Academic advisors are the first, most significant, and most consistent point of contact between the student and the university (Nandedkar, Mbindyo \& O'Connor, 2020). They guide and mentor students throughout their stay in college. Academic advisors are a key point of contact for students at the university and are uniquely positioned to help them successfully manage college and prepare for life beyond college (Nandedkar, Mbindyo \& O'Connor, 2020). Advisors are an important part of each student's education and guide their students through their academic journey and serve as a liaison to the broader university and the world beyond (O'Connor, 2016). Transformational leaders in all fields are supportive (Yukul, 2006), creative, innovative, empowering (Hackman \& Johnson, 2004), motivating, and inspiring (Bass, 1999). They possess the qualities of building a vision and commitment to their followers (DiFranza, 2019).

As previously stated, this conceptual paper aims to link the TL theory to the practice of academic advising. Our research argues that there are several similarities between the TL Theory and academic advising, and they have a similar underlying goal which is the growth and development of their followers in the case of TL theory and students in case of academic advising. In this paper, we also link TL theory to academic advising by analyzing the NACADA core competencies and core values and by integrating the four I's of TL into academic advising practices. We provide a rationale for the positive relationship between TL theory and academic advising practices and how by integrating TL Theory into advising we can help advisors become Transformational Leaders. Please see Figure 2 below which illustrates the link between the framework and the advising core values. 
FIGURE 2

COMPARISON OF TL 4IS TO NACADA`CORE VALUES

\begin{tabular}{|l|l|}
\hline Transformational Leadership 4Is & NACADA Core Values \\
\hline Idealized Influence & Respect and Integrity \\
\hline Inspirational Motivation & Empowerment \\
\hline Intellectual Stimulation & Professionalism and Commitment \\
\hline Individualized Consideration & Caring and Inclusivity \\
\hline
\end{tabular}

\section{IMPLICATIONS}

This article contributes to the existing literature in several ways. Firstly, our article shows that the 4 I's of TL can be extended to accommodate the work needs of academic advisors. Our work extends the understanding about the role of TL on academic advisors' work and student success. There is evidence that TL may produce maximum and best task performance of academic advisors (Nandedkar, Mbindyo \& O'Connor, 2020; Pine, 2020; Kelly 2003; Peters, 2014; Kincanon 2009; Spratley, 2020). The article also extends the TL approach by identifying the role of proactive characteristics in the effectiveness of advisors. In addition, our work contributes to prior research by providing support for the positive impact of TL on academic advisors. It helps advisors understand their value as leaders in their advising responsibilities across institutions by the 4Is. In the following paragraphs, the authors show the implication of the 4I's and how they complement the NACADA Core Values by helping advisors realize the characteristics and the skills needed in advising.

Inspirational Motivation is directly linked with the NACADA Core Value of Empowerment and is recognized as a key contributor to employee dedication and success in an organization (Pine, 2020; Bass, 1985; Bass \& Riggio, 2006). It can likewise be employed to increase motivation and dedication in students. Committed academic advisors are focused on motivating and encouraging students to do their best while supporting them in recognizing their potential and handling academic challenges. The advisors can utilize inspirational motivation to create a strong sense of academic achievement among students through Intentional motivation sessions. We emphasize the need to understand students and encourage them through inspirational motivation as it is shown to positively predict academic success (Pine, 2020; Nandedkar, Mbindyo \& O'Connor). As such, advisors should incorporate inspirational motivation concepts and its associated behaviors into academic advising sessions. They can also use inspirational motivation to sustain students' motivation towards improved social engagement. Incorporating Inspirational Motivation in their advising work, academic advisors can yield intrinsic motivation, commitment, and effort, which should culminate in improved student outcomes (Peters, 2014; Kelly 2003).

As already seen, individualized Consideration can be described as giving personal attention to subordinates and is directly linked to NACADA`s Core Value of Caring and Inclusivity. Each subordinate is accorded customized service based on his or her needs and abilities (Bass, 1985). As applied to academic advising, individualized consideration includes a customized plan for each of their students. This TL tenet allows the advisor to better assist a student in their career direction. The nature of the work demands that Academic advisors display caring attitude and are responsive and accessible to others in ways that challenge, support, nurture, and teach students to be the best. Individualized consideration enhances the advisor's capacity to build relationships through empathetic listening and compassion for students, colleagues, and others. Academic advising is central to a student's educational process and affects students in various ways, one of which is to foster individual potential (Drodz, 2010). This means that advisors know each of their students individually and listen to any concerns or needs they may have including encouraging students to be personally invested in their own success. In addition, caring means that the advisor is wearing the hat of a mentor and coach while working to develop, empower and inspire students to achieve more and to aim for the stars (McCleskey, 2014). This individual effort is key to achieving the best results and creating 
successful students. In addition, advisors strive to create supportive environments that are respectful of equity and diversity for the success of all students.

Intellectual Stimulation relates to the NACADA Core Value of Professionalism and Commitment and is demonstrated in the way advisors help students to think critically and consider new and innovative ways to solve problems (Barbuto, Story, Fritz, \& Schinstock 2009). Good advising requires knowledge and a clear understanding of the academic policies and the regulations laid out by the University. It requires collaboration and consultation with other offices on campus in service to the students in the best way possible. Academic advisors must therefore develop relationships with personnel critical to student success including faculty, staff in admissions, orientation, instruction, financial aid, housing, health services, athletics, academic departments, and the registrar's office (Nandedkar, Mbindyo \& O'Connor). They also must have connections with staff who work in learning or disability services, tutoring, psychological counseling, international programs, and career development to refer students as needed. Commitment requires dedication to the work helping students succeed. In addition, advisors are responsible for their professional development where they seek opportunities to grow professionally so that they can be better professionals. Related to this is the identification of appropriate training, research publications that would help them hone their professional skills, and advance expertise within specific areas of student development. Advisors who intellectually stimulate seek cross-cultural opportunities to interact with and learn more about different cultures and ethnicities to encourage students from different backgrounds. Commitment is the core of professionalism and enriches relationships. Students must be encouraged to be committed to their studies to do well. Without commitment, they will not succeed. Commitment stresses excellence through scholarly inquiry and life-long learning. So this particular tenet of $\mathrm{Tl}$ which is Intellectual Stimulation is critically important to the advisor as they work with students.

Finally, Idealized Influence is linked to the NACADA Core Value of Respect and Integrity. Respect is key in advising as it helps advisors to build trust with advisees. As advisors model integrity and respect toward those around them they demonstrate a passion for advising and a true commitment to cause positive change in the lives of the students. For students to be successful, advisors build positive relationships with them by understanding and appreciating students' perspectives and by maintaining a student-centered approach and mindset. They do so by making sure they are fair and sensitive to student's needs. Advisors are guided by a set of individual values which may lead in students' trust and emulation of positive behaviors especially if they are perceived as role models. Their confidence in how they "walk the talk" shows that they fulfill what they expect students to do and can be counted on. Because of this, students look up to them as role models (Nandedkar, Mbindyo \& O'Connor, 2020). Idealized Influence in advising means that advisors are serving with integrity and ethical standards. Integrity is an important virtue to have and for academic advisors, they must always exhibit ethical and professional behavior. They must pursue honesty, transparency, and accountability to the student, institution, and the advising profession. Developing integrity means academic advisors are reviewing personal values which help them to do their work honestly (Sprately, 2020). Students are quick to take note of what advisors do and use it as a template for how they act and behave even in academics (National Academy of Sciences, 1997). It happens automatically and subconsciously especially if students are looking upon the advisor as a role model. Therefore, advisors can help students recognize that the same values of integrity exist in their academics especially around academic integrity.

\section{CONCLUSION}

The goal of this paper is to apply the TL theory to the academic advising domain. Numerous studies in the organizational behavior and psychology literature have reported positive outcomes associated with TL, and we argue that by training advisors to model the behaviors of transformational leaders, the process of advising can be improved tremendously. The paper provides an explanation on how advisors can develop as transformational leaders by systematically including the 4 I's associated with TL theory in their advising repertoire and positively transform their advisees' journey in the college. We hope that this piece of work 
will provide a platform for scholars to pursue more research in the academic advising domain with the goal of enhancing the advising effectiveness and better student outcomes.

\section{REFERENCES}

Banerji, P., \& Krishnan, V.R. (2000). Ethical preferences of transformational leaders: An empirical investigation. Leadership and Organization Development Journal, 21(8), 405-413. https://doi.org/10.1108/01437730010358161

Barbuto, J.E., Jr. (2005). Motivation and transactional, charismatic, and transformational leadership: A test of antecedents. Journal of Leadership and Organizational Studies, 11(4), 26-40. https://doi.org/10.1177/107179190501100403

Barbuto, J.E., Jr., Story, J.S., Fritz, S.M., \& Schinstock, J.L. (2011). Full range advising: Transforming the advisor-advisee experience. Journal of College Student Development, 52(6), 656-670. https://doi.org/10.1353/csd.2011.0079

Bass, B.M. (1985). Leadership: Good, better, best. Organizational Dynamics, 13(3), 26-40. https://doi.org/10.1016/0090-2616(85)90028-2

Bass, B.M. (1999). Two decades of research and development in transformational leadership. European Journal of Work and Organizational Psychology, 8(1), 9-32. https://doi.org/10.1080/135943299398410

Bass, B.M., \& Riggio, R.E. (2006). Transformational leadership (2nd ed.). Lawrence Erlbaum Associates Publishers.

Bass, B.M., Avolio, B.J., Jung, D.I., \& Berson, Y. (2003). Predicting unit performance by assessing transformational and transactional leadership. Journal of Applied Psychology, 88(2), 207-218. https://doi.org/10.1037/0021-9010.88.2.207

Bolkan, S., Goodboy, A.K., \& Griffin, D.J. (2011). Teacher leadership and intellectual stimulation: Improving students' approaches to studying through intrinsic motivation. Communication Research Reports, 28(4), 337-346. https://doi.org/10.1080/08824096.2011.615958

Bryman, A. (2007). Effective leadership in higher education: A literature review. Studies in Higher Education, 32(6), 693-710. https://doi.org/10.1080/03075070701685114

Burns, J.M. (1978). Leadership. Harper \& Row.

Burt, T.D., Young-Jones, A.D., Yadon, C.A., \& Carr, M.T. (2013). The advisor and instructor as a dynamic duo: Academic motivation and basic psychological needs. NACADA Journal, 33(2), 4454. https://doi.org/10.12930/NACADA-13-006

Caruso, D.R., \& Wolfe, C.J. (2001). Emotional intelligence in the workplace. In J. Ciarrochi, J.P. Forgas, \& J.D. Mayer (Eds.), Emotional intelligence in everyday life: A scientific inquiry (pp. 150-167). New York, NY: Psychology Press.

Chickering, A.W. (1994). Empowering lifelong self-development. NACADA Journal, 14(2), 50-53. https://doi.org/10.12930/0271-9517-14.2.50

Conger, J.A. (1999). Charismatic and transformational leadership in organizations. Leadership Quarterly, 10(2), 145-179. https://doi.org/10.1016/S1048-9843(99)00012-0

Council for the Advancement of Standards. (2014). Higher Education. In CAS standards for leadership programs.

Crosbie, R. (2005). Learning the soft skills of leadership. Industrial and Commercial Training, 37(1), 4551. https://doi.org/10.1108/00197850510576484

Davis Jones, C.L. (2016, March 4). The full Range Advising experience: An assessment of college Academic advisors'SELF-PERCEIVED leadership styles. UNT Digital Library. Retrieved September 21, 2021, from https://digital.library.unt.edu/ark:/67531/metadc804934/m1/147/

DiFranza, A. (2019). Transformational leadership: How to inspire innovation in the workplace. Retrieved May 23, 2021, from https://www.northeastern.edu/graduate/blog/transformational-leadership/

Drozd, D.S. (2010). Student preferences for academic advisors as transformational leaders (Doctoral dissertation, Texas A\&M University). 
Gallup, Inc. (2017, October 19). State of the Global Workplace. Gallup Press. Retrieved from www.gallup.com/workplace/238079/state-global-workplace-2017.aspx

Gheith, N.A.R. (2010). Reconstructing organization culture through enforcing head nurse's transformational leadership style. Australian Journal of Basic and Applied Sciences, 4(6), 12881296.

Gillispie, B. (2003). History of academic advising. Retrieved from http://www.nacada.ksu.edu/Resources/ Clearinghouse/View-Articles/History-of-academic-advising.aspx

Gordon, V.N., Habley, W.R., \& Grites, T.J. (2008). Academic advising: A comprehensive handbook (2nd ed.). Jossey-Bass.

Green, E.D. (2016). Advisors as leaders: An explanatory study of the perceptions that professional undergraduate academic advisors have about leadership development skills. Wayne State University dissertations. Retrieved from https://digitalcommons.wayne.edu/oa_dissertations/1537

Grites, T.J. (2013). Developmental academic advising: A 40-year context. NACADA Journal, 33(1), 5-15. https://doi.org/10.12930/NACADA-13-123

Hackman, M.Z., \& Johnson, C.E. (2004). Leadership: A communication perspective. Waveland Press.

Higgins, E. (2017). The advising relationship is at the core of academic advising. Retrieved from https://nacada.ksu.edu/Resources/Academic-Advising-Today/View-Articles/The-AdvisingRelationship-is-at-the-Core-of-Academic-Advising.aspx

Kelly, M. (2003, January 1). Academic advisers as transformational leaders. The Mentor: An Academic Advising Journal, 5(1). Retrieved from http://www.psu.edu/dus/mentor/030101mk.htm

Kevin Kelloway, E.K., Barling, J., Kelley, E., Comtois, J., \& Gatien, B. (2003). Remote transformational leadership. Leadership and Organization Development Journal, 24(3), 163-171. https://doi.org/10.1108/01437730310469589

Kincanon, K. (2009). Translating the Transformative: Applying Transformational and Self-Authorship Pedagogy to Advising Undecided/Exploring Students. Retrieved September 20, 2021, from http://www.nacada.ksu.edu/tabid/3318/articleType/ArticleView/articleId/647/article.aspx

Kirkbride, P. (2006). Developing transformational leaders: The full range leadership model in action. Industrial and Commercial Training, 38(1), 23-32. https://doi.org/10.1108/00197850610646016

Koen, M.P., \& Bitzer, E.M. (2010). Academic Leadership in Higher Education: A "participative" Perspective from One Institution. Academic Leadership: The Online Journal, 8(1), article 8. Retrieved from https://scholars.fhsu.edu/alj/vol8/iss1/8

Larson, J., Johnson, A., Aiken-Wisniewski, S.A., \& Barkemeyer, J. (2018). What is academic advising? An application of analytic induction. NACADA Journal, 38(2), 81-93.

Marks, L.I., \& Wade, J.C. (2015). Positive Psychology on Campus: Creating the Conditions for WellBeing and Success. About Campus, 19(6), 9-15.

McClellan, J., \& Moser, C. (2011). A practical approach to advising as coaching. Retrieved from http://www.nacada.ksu.edu/Clearinghouse/AdvisingIssues/advising-as-coaching

McClellan, J.L. (2007). The advisor as servant: The theoretical and philosophical relevance of servant leadership to academic advising. NACADA Journal, 27(2), 41-49.

McCleskey, J.A. (2014). Situational, transformational, and transactional leadership and leadership development. Journal of Business Studies Quarterly, 5(4), 117-130.

McMahan, A.B. (2008). How to become an academic advisor. NACADA Clearinghouse. Retrieved from https://nacada.ksu.edu/Resources/Clearinghouse/View-Articles/Become-an-Advisor.aspx

Morris, A., \& Miller, M. (2007). Advising practices of undergraduate online students in private higher education. Online Journal of Distance Learning Administration, 10(4).

Nandedkar, A., Mbindyo, M., \& O'Connor, R.J. (2020). Advisor transformational leadership and its impact on advisees: A conceptual analysis. Journal of Higher Education Theory and Practice, 20(14), 156-169.

National Academy of Sciences-National Research Council, Washington, DC., Mathematical Sciences Education Board, National Academy of Sciences, National Academy of Engineering Staff, National Academy of Sciences Staff, National Academy of Engineering, \& Global Affairs Staff. 
(1997). Adviser, teacher, role model, friend: On being a mentor to students in science and engineering. National Academy Press.

Northouse, P. (2010). Leadership: Theory and practice (5th ed.). SAGE.

O’Connor, R. (2017). Academic Advising and College Stressors in a Large, Urban University.

[Unpublished doctoral dissertation]. University of Pittsburgh.

Peters, J.M. (2014). Transformational teachership: How principles of transformational leadership foster student outcomes. (Doctoral Dissertation, Colorado State University).

Pine, C.L. (2020). Academic advisors displaying transformational leadership behaviors perceived effects on student motivation. 1006744 Bytes. https://doi.org/10.25394/PGS.13274552.V1

Reeve, J., Nix, G., \& Hamm, D. (2003). Testing models of the experience of self-determination in intrinsic motivation and the conundrum of choice. Journal of Educational Psychology, 95(2), 375.

Schuh, J.H., Jones, S.R., \& Harper, S.R. (Eds.). (2010). Student services: A handbook for the profession. John Wiley \& Sons.

Smith, W.E., III. (2020). Empathy: Advise with care. Academic Advising Today, 43(2).

Spratley, S. (2020). Exploring the role of the academic advisor in leadership education. Journal of Leadership Education, 19(2).

Surr, W. (2019). Student Advising: An Evidence-Based Practice. Midwest Comprehensive Center.

Towler, A. (2019). The qualities of transformational leaders and what distinguishes them from transactional leaders. CQ Net-Management Skills for Everyone. Retrieved from

https://www.ckju.net/en/dossier/qualities-transformational-leaders-and-what-distinguishes-themtransactional-leaders\#: : :text=Individualized\%20Consideration\%20is\%20the\%20extent,each\%20 person'\%20 situation\%20and\%20background

van Ameijde, J.D.J., Nelson, P.C., Billsberry, J., \& van Meurs, N. (2009). Improving leadership in Higher Education institutions: A distributed perspective. Higher Education, 58(6), 763-779.

White, E.R. (2015). Academic advising in higher education: A place at the core. Journal of General Education, 64(4), 263-277.

Young-Jones, A.D., Burt, T.D., Dixon, S., \& Hawthorne, M.J. (2013). Academic advising: Does it really impact student success? Quality Assurance in Education, 21(1), 7-19.

Yukl, G. (2006). Leadership in Organizations (6th ed). Pearson Education.

Zhang, X., Li, N., Ullrich, J., \& van Dick, R. (2015). Getting everyone on board: The effect of differentiated transformational leadership by CEOs on top management team effectiveness and leader-rated firm performance. Journal of Management, 41(7), 1898-1933. 